\title{
DECONSTRUCTING NEOLIBERAL HEGEMONY
}

\author{
Corinna Lotz \\ International Friends of Ilyenkov \\ Penny Cole \\ International Friends of llyenkov
}

\begin{abstract}
Neoliberal hegemony or power is seen as the contemporary form of capitalism, a socialhistorical formation with three dialectically-related aspects: the state, the economic system and ideological systems. These exist side by side and are interconnected and interdependent but they are not identical. Considering these aspects "in themselves" is a challenge, because the economic foundations of neoliberal capitalism are frequently viewed as a seamless, monolithic, omnipotent social system. The paper examines the contradictions with the neoliberal Ideal, drawing on the approach of the oppositional Soviet philosopher Evald Ilyenkov. The Ideal is internally contradictory and therefore "unquiet" with the power to stimulate action. It exists in a negated way within the individual but also has an independent existence outside the individual. It is objective because it is not the property of, or nor does it arise from one individual's actions in the world: it is the objective form of the whole social existence of human beings.
\end{abstract}

Keywords: Neoliberal. Hegemony. Capitalism.

\section{Introduction}

$\mathrm{T}$

he International Friends of llyenkov have been sharing their work on contemporary philosophical and political challenges since 2012. At this, our second symposium, we build on the collective reading and discussion of llyenkov's writings and theoretical work carried out in different disciplines by IFI members since then. The aim is to develop holistic, this-sided dialectical concepts ${ }^{1}$ that probe and reveal the parts and their dialectical relationship to the whole of today's neoliberal capitalist society.

This approach helps us understand hegemony as a complex of self-related opposites as well as a social-historical formation. We are informed by llyenkov's work on the contradictory nature of the Ideal and his work in demonstrating the movement from the

\footnotetext{
${ }^{1}$ Karl Marx, Theses on Feuerbach: The question whether objective truth can be attributed to human thinking is not a question of theory but is a practical question. Man must prove the truth - i.e. the reality and power, the this-sidedness of his thinking in practice. The dispute over the reality or non-reality of thinking that is isolated from practice is a purely scholastic question.
} 
abstract to the concrete and to practice. We probe its internally contradictory nature to discover and help shape forces that can move beyond it.

Neoliberalism is the contemporary form of capitalism, the system of commodity production and exchange for profit in its post-Keynesian, globalised, super-marketised phase. Friedrich Hayek and other economists first theorised neoliberalism as economic concepts in the 1930s. But they were only introduced as an organising idea following the collapse in the early 1970 s of the post-war "managed economy" established by the Bretton Woods arrangements towards the end of World War II.

Following a period of oil shocks, stagflation and conflicts with a then powerful trade union movement, neoliberalism took the form of state practice. This occurred first in Chile under Pinochet, in 1973, followed most dramatically in the UK under Margaret Thatcher from 1979 onwards, and soon after by Ronald Reagan in the United States. In its second phase, neoliberalism was developed by the governments of Bill Clinton and Tony Blair. The closing decades of the 20th century saw the process speeded up. Transnational corporations and a global financial system operating $24 / 7$ and beyond borders became dominant.

An ideological offensive to assert power was accompanied by phenomena such as the rise of the brand and a powerful expansion of images. This developed into a new kind of hegemony in which post-modern notions were a distinct part of the mix. Despite the financial crash of 2007-8, the late 20th century form of capitalism did not disappear but has staggered on, albeit in what some describe as zombie forms.

Hegemony, in the Gramscian sense, signifies the political and cultural domination of one class over others. Power is exercised through ideologies and control mechanisms not simply brute force. The hegemony of neoliberalism, as Stuart Hall has stressed, is never a completed project. It is a process, not a state of being - "No victories are permanent or final", to quote Jim McGuigan.

Neoliberal hegemony or power has three dialectically-related aspects: the state, the economic system and ideological systems. These exist side by side and are inter-connected and inter-dependent but they are not identical. Considering these aspects "in themselves" is a challenge, because the economic foundations of neoliberalism and its ideology, including its "structures of feeling" (Lawn and Prentice), are frequently viewed as a seamless, monolithic, omnipotent social system. 
Neoliberal hegemony is most significantly exercised through the capitalist type of state which historically creates the framework for the accumulation of capital and has changed its form in relation to neoliberalism (Jessop). However, the pivotal role of the state, whose alienated institutions actually exercise day-to-day power over society, is commonly ignored even though it plays the central role in generating and enforcing capitalist hegemony. Because the state is not a single entity but an array of institutions that wield power, it exists yet does not exist at the same time. Indeed, more than the market, the state is the "invisible hand" that creates the enabling legal and ideological framework for the perpetuation of the system of private ownership and production for profit. As Bob Jessop explains:

[First] the state protects private property and the sanctity of contracts on behalf of capital as a whole. This supports capital's formal rights to manage the labour process, appropriate surplus labour, and enforce contracts with other capitals. Second, the rational organisation of capitalism requires free wage labour - which the state creates through its role in ending feudal privileges, promoting the enclosure of commons, punishing vagabonds, and imposing an obligation to enter the labour market... Third, the modern state does not engage in profitable economic activities on its own account - capital prefers to provide these and gets the state to undertake economically and socially necessary activities that are unprofitable.

State intervention has been transformed rather than reduced under neoliberalism. The naked power of financial capital has come to the fore as never before, as SOAS academics Ben Fine and Alfredo Saad-Filho explain:

Currently, while the overall logic of state policies and interventions remains to promote economic and social reproduction and the restructuring of capital, the interests and role of finance have increasingly come to the fore either directly or indirectly. Such is evident, for example, from the policy responses to the global crisis and the continuing recession; but it is equally characteristic of the policies implemented over the entire neoliberal period, as the interests of private capital in general and of finance in particular have been favoured by the state.

This standpoint is reinforced by William Davies, who describes the state as a "central instrument for the advancement of a neoliberal agenda". He adds: "Commitment to a strong state, capable of rebuffing political and ideological challenges to capitalist competition, is a defining feature of neoliberalism, both as a system of thought and of applied political strategy."

Ordinarily, it is impossible to identify the state in a concrete material form. Only when it exerts its power as a physical force in "bodies of armed men" (Lenin) does its essence turn 
into appearance. Like all Ideal forms, including value and indeed democracy, it only exists in the form of human social activity.

That active moving framework directly determines the forms of existence that millions of people engage in day in and day out, such as working, shopping and consuming commodities, studying and organising family and social life. These repeated actions give rise to forms of thought which become social norms.

These social norms also become part of our mental outlook as "givens", in which class interest lies buried. As Russian revolutionary leader V.I. Lenin noted in his philosophical notebooks, our categories of thought, logic and the Ideal are abbreviations for the "endless multitude of particulars of external existence and of action", before adding emphasis to Hegel's words: "In this kind of thought, 'those interests [e.g. the state] are hushed which move the lives of peoples and individuals"'.

\section{Neoliberal realities and ideology: being and consciousness}

Neoliberal hegemony is sustained by the new forms of production and trade that first established themselves in the advanced capitalist economies and have since been adopted by so-called emerging economies like India and former non-capitalist states like China. In the older economies, increasing numbers have been thrust down into the precariat, deprived of stable jobs and a living wage. Instead they endure zero-hours contracts, without security, without holiday or sick pay, or short-term contracts that destabilise family and social life. In the gig economy, platform enterprises in the shape of Uber and others now wield enormous power.

The proliferation of privatised former public services means that workers have lost much of their collective bargaining strength and soon come up against anti-union legislation that prevents effective strike action. In economies sustained by personal borrowing, hegemony is reinforced by levels of household debt in countries like the UK that were last seen on the eve of the 2008 crash.

A key feature of neoliberal hegemony is that it claims not to have its own ideology, thus obliterating any distinction between being and consciousness. It claims there is no a priori distinction, as political economist William Davies has noted, between the realm of the "political' and that of the "economic". For Fine and Saad-Filho, neoliberal ideology has a kind of positive and seductive logic: 
[...] an individualist, formally egalitarian, meliorist and universalist conception of self and society. This worldview justifies a set of loosely articulated finance-friendly state policies and practices giving neoliberalism a semblance of coherence in the realm of ideas, and considerable resilience in practice: these policies cannot be contested easily, for the neoliberal restructuring of the economy and society not only narrows drastically the scope for, and directions of, debate, but also hollows out the institutional channels from which alternatives could emerge.

Masquerading as "anti-ideology", this point of view serves the system well. Many of those who seek to critique neoliberalism are caught in the trap of fusing or conflating its ideology with its economic structures, particular post-structuralist thinkers and their contemporary heirs in academic departments of sociology. (Levant, Mclntyre) But a materialist dialectical view of the neoliberal Ideal can, and indeed must, unravel the real from the Ideal.

What are the neoliberal Ideals?

While there are many different theories of neoliberalism, they can be summed up in the following:

- Free individuals are said to operate within the level playing field of a universal free market.

- There is no such thing as society, only individuals and families", Thatcher infamously asserted.

- We are sovereign individuals, free to make choices about work, life style and consumption.

- The free market, together with risk-taking entrepreneurs and hardworking taxpayers, delivers our basic needs and more, if we are sufficiently ambitious and creative.

- The main role of the state is to create the institutional framework for this approach, promoting free trade, deregulation and creating new partnerships with the corporate sector.

- Things may not be perfect but it is the best of all possible systems.

- Other "belief systems" must inevitably lead to the repression of the individual, totalitarianism, bureaucracy and a miserable life.

Neoliberalism is upheld and reinforced by global bodies like the World Trade Organisation and the International Monetary Fund and regional blocs such as the European Union. A powerful group of policy groups led by the World Economic Forum, the Mont Pelerin Society and the International Chamber of Commerce constantly develop the ideological framework of neoliberalism, which is then advocated at state level. For example, an 
estimated 30,000 corporate lobbyists work in Brussels, directly influencing the work of the EU.

Some liberal ideals such as anti-racist legislation, women's, minority and gender rights also form part of liberal and neoliberal belief systems. While they are claimed as successes by liberal and neoliberal politicians (most recently the anti-abortion vote in Ireland) the struggle to enshrine these in legislation has been against the political, religious, state and moral authorities of the day, going back deep in time.

Ilyenkov and the Ideal

Thus Ideals have more than one abode in time and place and contain an inherently restless quality. This is why, at the IFl's first conference in 2014 in Helsinki's Centre for Activity, Development and Learning, we celebrated the translation into English of Evald Vassilievich Ilyenkov's The Dialectics of the Ideal. We sought to understand the nature of the Ideal and its contradictions in our time.

Ilyenkov worked for an understanding of the Ideal as independent of individual human consciousness. This was (and is) in opposition to the view that the Ideal and Ideality are psychological, neurological constructs of individual consciousness - a key issue in the deconstruction of neoliberal ideology. He did this by building on Hegel, Marx and Lenin's critiques of Kantian and positivist thinkers of his time.

In this view, the starting point for cognition is the relationship between the objective movement of the physical world and thought, which takes place through practical human activity, including mental labour. The immediate connection is through sensation, the source of which is the reflection of the movement of matter.

Sensations arise in the context of our existence as social beings in the imagedominated world of contemporary globalised corporate capitalism. But the development of thought is not limited simply to what goes on around us or whatever activity we may be involved in. The Ideal has an existence independent of consciousness which includes in a negated way the entire history of human beings on the planet. There is thus an objective, contradictory content to the Ideal. (Lotz-Feldman-Cole-Gold 2014).

The Ideal arose and continues to exist through collective, historical human activity. The human individual forms and shapes itself, humanises her or himself by its practical activities in the context of the society which includes a whole range of ideal forms. Ideals are part of human social being and exist outside and beyond individuals or social classes.

The Ideal is internally contradictory. It exists in a negated way within the individual but also has an independent existence outside the individual. It is objective because it is not 
the property of or nor does it arise from one individual's actions in the world - it is the objective form of the whole social existence of human beings. The Ideal is not actualised by the brain for itself, and the making of a new counter-hegemonic revolutionary subject requires a social, collective effort.

At crucial moments the Ideal begins to take on a new active existence as a force for change in the consciousness of millions of individuals.

As Ilyenkov wrote in Dialectics of the Ideal (p.77-78):

The ideal form is a form of a thing, but outside this thing, namely in man, as a form of his dynamic life-activity, as goals and needs. Or conversely, it is a form of man's dynamic life-activity, but outside man, namely in the form the thing he creates, which represents, reflects another thing, including that which exists independently of man and humanity. 'Ideality' as such only exists in the constant transformation of these two forms of its 'external incarnation' and does not coincide with either of them taken separately. It exists only through the unceasing process of transformation of the form of activity into the form of a thing and back - the form of a thing into the form of activity (of social man of course)."2

\section{So, what are the contradictions within the Ideal of contemporary hegemony?}

The neoliberal economic Ideal of free markets is, in practice, rigged semi-monopoly markets that are controlled by a handful of corporations in each sector.

Moreover, the notion that all individuals benefit is in stark contradiction to reality. The market is said to guarantee the essentials of life, yet it is failing to provide. Despite a phenomenal productive capacity, safe food, affordable housing, healthcare and sustainable jobs are increasingly out of reach. An estimated $42 \%$ of workers globally are in vulnerable employment, while global unemployment for young people at $13 \%$ is three times higher than for adults. Plentiful resources like water are becoming costly. Even fresh air is increasingly hard to come by. Inequality is more striking than ever. The world's richest $1 \%$ are on course to control as much as two-thirds of the world's wealth by 2030 .

Neoliberalism is more unstable than previous periods of capitalism as a result of the detachment of the financial system from other sectors of the economy. "Financialisation" means that significant sectors of the global economy are driven by the pursuit of rent on financial instruments and assets. Global debt is well out of control, standing at \$164 trillion,

\footnotetext{
2 Translation note by Alex Levant: In Ilyenkov: the term 'man' does not typically refer to a human being, but to social man. For instance, see the following passage from page 3 of Dol: "It is the form of a thing but exists outside this thing - namely, in the activity of the human being as a form of this activity. Or the other way around, it is a form of activity of a human being, but outside this human being, as the form of a thing'." By translating "человек" as 'human being', the social character of "человек" is lost. Hence, activity appears as individual activity, and the meaning of the passage becomes something very different from what llyenkov meant.
} 
and larger by some estimates. Instead of helping with growth and investment, it acquired an overwhelming destabilising power of its own. Crises beginning in the financial sector are more frequent more contagious, and more systemically damaging than ever before.

The authority of the state, which is essential for the development of the neoliberal project, has been weakened and suffers from an increasing loss of legitimacy. This is the result of its partisanship in the contemporary period, whereby it favours corporate and financial interests over public interests, most significantly during the $2008 \mathrm{crash}$. A crisis of representative democracy is self-evident, with the emergence of autocratic regimes. The hollowing out of the liberal form of democracy demonstrates that capitalism can and does dispense with even the outer forms of democracy when required.

There are huge advances in our scientific understanding of the planet and life and yet the planet is being fatally damaged in ways that (seemingly) no-one has the power to control. A profound ecological crisis corresponds with, and is magnified, by the current period of capitalism which has led to unparalleled carbon emissions, the destruction of species and accelerated climate change. International agreements have merely reinforced the neoliberal, market-led approach and have made little impact.

The digital-communications revolution and the Internet have made much information and knowledge freely available. At the same time "post-truthers" - backed by reactionary political and corporate forces, use it to prey on superstition and backwardness. Evidence-based research is placed in doubt. Social media and digital technology can and do enable instant communication through which people can relate to each other and overcome isolation, overcoming physical distance. And yet loneliness and mental illness are on the rise.

\section{Commodity fetishism and the self}

Jim McGuigan has pointed to the contradictory nature of The Neoliberal Self - the title of his 2014 essay in Culture Unbound. An ironic stance towards "the system" allows people to appear as rebels when in fact they are conforming to an Ideal of the self that is consonant with the neoliberal "ethos". Of course this has its attractions - freewheeling consumer sovereignty combined with enterprising business acumen - a "cool-capitalist way of life", typified by successful "ideal types" such as Mark Zuckerberg and the late Steve Jobs.

But its downside is that when things go wrong, the individual is often "penalised harshly not only for personal failure but also for sheer bad luck in a relentlessly harsh social 
environment". We see the costs of this every day in rapidly rising mental illness and suicide rates, amongst the young, especially at exam time. Thus, as McGuigan says, individualism "is better understood not so much as the bourgeois ideal of personal freedom but as compulsory individualisation instead".

Instead of a multi-sided real individuality, the Ideal neoliberal self is an artificial, onesided construct that in real life can become a "terrifying straitjacket haunted by the ever present possibility of failure". The extreme nature of marketisation and its manufactured Ideals have created unbearable tensions. Contained within the consumer society is a fundamental contradiction between the human being and the inhuman nature of capital.

llyenkov, following Marx, focuses on how the commodities that we consume are independent things which exist outside human beings, but which at the same time are a form of human "dynamic life-activity, as goals and needs".

The objects that human beings have created themselves take on the appearance of "eternal and unalterable forms and relations between things, as relations dictated by 'laws of nature'." (Dol p.76) In the alienated, fetishised, topsy-turvy world of consumer neoliberalism, human beings are dominated by the inhumanity of the very objects (commodities such as iphones for example) and systems (such as call centres and the transaction platform economy) that they labour to create. Thus, in developing dialectical concepts, to unravel the underlying cause from its effects, we need to do as William Davies proposes: "decouple the notion of social and political from neurological causality".

\section{Limitations of Post-Structuralism}

Alongside the development of illiberal capitalism has been the rise of post-truth and "fake news", most notoriously under the Trump presidency and Putin's fourth reelection. And here's where llyenkovian concepts can potentially help overcome the limitations of post-structuralism.

US philosopher and science historian Lee McIntyre revealingly traces some of the roots of post-truth to the science denial conspiracies by Big Tobacco and Big Oil. He also details how powerful autocrats, assisted by armies of money-grubbing hackers and troll farms, are exploiting social media to prey on cognitive bias and gullible subjects to gain political and electoral influence.

McIntyre lays a great deal of responsibility for post-truth at the door of poststructural philosophers. Literature departments working with the ideas of Derrida, Foucault, 
Deleuze and Guattari in literary criticism, and social constructivists in science shared the idea that truth was perspectival and that all knowledge was socially constructed. Scientists fought back against what was considered the "academic left", but without the benefit of a dialectical approach which helps explain how knowledge is indeed historically conditioned but nonetheless able to arrive at objectivity. In other words, the truth of things and the process of determining it is both relative but also partakes of an aspect of the universal, absolute.

Many post-structuralist thinkers, Foucault in particular, were prescient and eloquent in their analysis of neoliberal capitalism's ideological forms. At the same time the subjective, relative forms of consciousness which they analysed and "deconstructed" were transformed into a new absolute, with no apparent relationship to any social being outside it or indeed any possibility of taking on the state as the lynchpin holding things together. This means of course that we can be trapped within individual forms of consciousness - a recycling of the very ideology that is being opposed.

The relativism of post-structuralism made it unable to theorise outside or beyond the very notion of an all-powerful all-embracing hegemonic system. If Ideal phenomena are understood as purely and only socially constructed forms, then relativism becomes the new absolute. There is nothing beyond the socially constructed world of neoliberal capitalism nor can there ever be. There Is No Alternative. Instead of being historicised, the social and economic system and its ideologies are fused together and eternally dissolved in individual perception.

Grasping the relationship between thought and being, between the Ideal and the Real as an objective material whole becomes impossible. The relationship between the whole and the part, the individual and the universal is severed.

But in Ilyenkov's richer, dialectical view, "Ideality is ... a characteristic of the materially established (materialised, reified, objectified) images of social-human culture, that is, the historically-formed modes of social-human life, which confront the individual possessing consciousness and will as a special 'supernatural' objective reality, as a special object comparable with material reality and situated on one and the same spatial plane (and hence often conflated with it)". (Dol, p.50).

In the approach developed by Lenin in his study of Hegel's Logic, and on which Ilyenkov drew, materialist dialectics is the theory and practice of approximating to an everchanging objectively existing reality. The truth of things is tested and realised through practical human activity. There is thus an objective absolute within the subjective and 
relative. (Lenin Vol.38 p.171) And the objective physical reality of human social being, while contiguous with individual consciousness, is not identical with it.

\section{Conclusions - developing the counter-hegemonic project}

The democratic Ideal is the main political and potentially revolutionary contradiction of our times. The Ideal of democracy is in conflict with both neoliberal capitalism and its state. Today's capitalism has shed its liberal side and became illiberal capitalism. The Ideal of democracy, which is much older and larger than its particular, temporal existence in capitalist society, must be negated into a more advanced form.

While not yet taking on the shape of a conscious movement, the opposite to the capitalist type of state - in favour of a truly democratic one - is pushing to emerge and be born. Giving the hollowed-out Ideal of neoliberal democracy a new, advanced, universal content can inspire the creation and organisation of new revolutionary subjects.

Political thinkers are expressing their fears in writing: Harvard professors Steven Levitsky and Daniel Ziblatt wrote How Democracies Die and Cambridge professor David Runciman has just published The Death of Democracy, amongst others. In the United States, Trump rules outside the constitution in a Bonapartist fashion. Autocracies now dominate many former Soviet states. Old parties have been swept aside by populists in France and Italy. In the UK, there is a political deadlock over Brexit, which itself can be seen as a rejection of neoliberalism and a failed parliamentary system.

Counter-hegemonic movements can be trapped in the mistaken notion that the present state is somehow a neutral entity which can be pressured into serving the interests of the $99 \%$. History has demonstrated repeatedly that this is not the case. Movements and parties such as Occupy, Podemos, Syriza and the Corbynistas have opposed austerity but sidestepped or ignored the nature of the state. The capitalist state, however, evicted Occupy, and the European Union state-in-formation organised the defeat of the antiausterity Syriza-led movement in Greece. In the UK, the state and the financial markets are preparing to confront Corbyn should he be elected.

A significant aspect of hegemony is to characterise the dominant system as an unalterable eternal. Part of this "eternal" is the invisible but omnipresent existence of the state - the thing that dare not speak its name. But the underlying, material reality of our relation with nature is the real universal and eternal relation. Consequently, the neoliberal 
self is alienated in multiple ways. It is alienated from its own human nature - from social, collective existence as well as from the biological nature on which all life depends.

At the same time, the reality of nature constantly asserts itself as the ground, the most basic and paramount requirement for our life on the planet. Whereas hegemony is a human-made and time-limited structure - a structure with its own laws of motion and containing contradictions which ensure that it is in transition to something else. The nature of that "something else" is not pre-determined and depends on conscious human action.

Neoliberal hegemony does not prevail due to an intrinsic superiority of its doctrines but because of the lack of an alternative ideology or counter-culture capable of exerting sufficient attraction on people's minds and spirits to overthrow it. Or as Fisher puts it:

One strategy is to invoke the Real(s) underlying the reality capitalism presents to us. Environmental catastrophe, stress and mental illness are amongst these realities. The 'mental health plague' in capitalist societies would suggest that instead of being the only social system that works, capitalism is inherently dysfunctional and the cost of its appearing to work is very high.

We should shift our focus on to the pulse of underlying and universal contradictions within the system, embracing all the multiple aspects which are currently separated into a host of "issues" and "identities". What is needed is not a "left-wing form of populism" but a revolutionary challenge to move beyond capitalism. How can the concept of individual agency be strengthened and connected with the power of the collective and vice versa?

A "cool" posture, while trying to be oppositional, can be in danger of dismissing and depreciating the reality of the Ideal and of Ideality, thus disarming those who seek to oppose neoliberal capitalism. This problem has been identified by thinkers like Slavoj Zizek and Mark Fisher: "Today's society must appear post-ideological: the prevailing ideology is that of cynicism; people no longer believe in ideological truth; they do not take ideological propositions seriously. ... Cynical distance is just one way ... to blind ourselves to the structural power of ideological fantasy: even if we do not take things seriously, even if we keep an ironical distance, we are still doing them." (Zizek quoted by Fisher in Capitalist Realism).

The Ideal of democracy has its own history and dynamic. It is not the property or plaything of the capitalist classes. The struggle for democracy is identical with the struggle against the state down the centuries. The struggle of social human beings throughout history has been to achieve real democracy. Or as Hegel put it, "world history is the progress of the consciousness of freedom, a progress which we have to know in its necessity". The Ideal of 
democracy can be considered the most dynamic and fundamental contradiction that has driven human history.

\section{Creating real Utopias}

Human beings do not live by bread alone. They are tied together by social relations, traditions, histories, idols and ideals which people have to a greater or lesser extent embraced and lived for. Taken literally, realising the ideals of democracy - the people in power - requires the creation of a more dialectical self in which the individual overcomes alienation from her or his social, natural being.

As the "free individual" Ideal of liberal and neoliberal capitalism faces the onslaught of the illiberal form, powerful and disruptive forces are being unleashed. It is fruitless to anticipate a kinder, more liberal form of capitalism, to envisage reforming the unreformable, to regulate that which cannot be regulated. It is more realistic to revolutionise society than to achieve a human form of capitalism. Developing notions of truly democratic structures in place of the capitalist state is the challenge before us.

Let us build on the approach of thinkers like llyenkov, Vygotsky and contemporary theorists in advancing the dialectical understanding of how the individual makes herself and himself as part of a social whole, a collective. Only in this way can a revolutionary subject become conscious and powerful.

William Davies proposes "the creation of real Utopias" - in other words, the transformation of the Ideal into the real. That transformation is impossible without first and foremost deconstructing the capitalist state. Creating real Utopias requires a more advanced, political understanding, so we could propose an ecological cultural historical activity theory (E-CHAT?) to encompass attractive new vistas and possibilities.

We could do worse than to sail with Oscar Wilde, who wrote:

A map of the world that does not include Utopia is not worth even glancing at, for it leaves out the one country at which Humanity is always landing. And when Humanity lands there, it looks out, and, seeing a better country, sets sail. Progress is the realisation of Utopias.

Negating more advanced, richer forms of democracy out of the present crisis requires a collective approach of many minds and plenty of energy. Hopefully the International Friends of Ilyenkov can contribute to such a project and the practical consequences that arise from it in terms of new forms of democratic organisation that can facilitate the transformation. Democracy, as the Greek word implies, is a contradictory 
dialectical whole - the people and power. In general the people have been denied real power. Now is the time to invest power in the people.

\section{REFERENCES}

Bakhurst, David. Lessons from llyenkov, The Communication Review, 1995.

Dardot, Pierre. Hegemony and Neoliberalism, Transform Network, 2012.

Davies, William. Afterword: The Limits of Neoliberalism, 2014.

Feldman, Paul. Unmasking the State, 2008.

Fine, Ben and Saad-Filho, Alfredo. Thirteen things you need to know about neoliberalism. SOAS research online 2017.

Fisher, Mark. Capitalist Realism, 2009.

Ilyenkov, Evald: Dialectics of the Ideal. Edited by Alex Levant and Vesa Oittinen, 2014.

Jessop, Bob. The State: Past, present and future, 2016.

Laclau, Ernesto. On Populist Reason, 2005.

Lawn, Jennifer and Prentice, Chris. Neoliberal culture/the cultures of neoliberalism. Sites, 2015.

Levant, Alex. Two, three, many strands of activity theory! Educational Review. 2018.

Levant, Alex. Smart Matter and the Thinking Body: Activity Theory and the Turn to Matter in Contemporary Philosophy Stasis, Vol. 52017.

Lenin, V.I. Conspectus of Hegel's Logic. Vol.38 Collected Works, 1972.

Lotz, Feldman, Cole and Gold. Contradictions within the Ideal, 2014.

Maidansky, Andrey and Oittinen, Vesa. The Practical Essence of Man, The "Activity Approach" in Soviet Philosophy, 2015.

Marx, Karl. Theses on Feuerbach, The German Ideology, 1845.

McGuigan, Jim. The Neoliberal Self, 2014.

McIntyre, Lee. Post-Truth, 2018.

Real Democracy Movement. Democracy Unchained, 2017. 
Real Democracy Movement. Time’s Up for Neoliberalism, 2018.

Srnicek, Nick and Williams, Alex. Inventing the Future: Post-capitalism and a world without work, 2015.

Venugopal, Rajesh. Neoliberalism as Concept, 2015.

Wilde, Oscar. The Soul of Man under Socialism. 1891. 